\title{
International Container Port System Concentration: What Does it Look Like?'
}

\author{
Prabir De and Ro-Kyung Park ${ }^{\circ *}$
}

\begin{abstract}
Since the 1980s the economic development of countries in East Asia has had a marked impact on the world port community, particularly in container transport. This paper analyses changes in the competitive environment of the world container port sector using some standard tools of market concentration. Initially, this paper reviews the competitive position of world container port system and then examines the East Asian economic environment. Both ordinal and cardinal measures of port system inequality are used to demonstrate both the rankings and levels of container throughput have been diverging in the world's major economic blocs. Conversely, East Asian countries during the 1990s have shown a trend towards convergence. Measures of dispersion suggest that ports in East Asian countries have become more competitive in their levels of container throughput.
\end{abstract}

Keywords: Container Port System, East Asia, Market Concentration, Port Terminal Operators.

\section{BACKGROUND}

The reason for focusing on the concentration of activities within the container port system is quite simple. Reducing the cost and improving the quality of the container port system increases a country's international market access. This increased access leads directly to greater trade and through this mechanism to higher incomes at a time when containerized cargo provides a greater part of global merchandise trade.

There is ample cross-country evidence that shows that the more a country opens its economy the more it generates container port traffic (see Figure 1). Those countries lying high above the fitted line score higher on measures of openness and are accessible to world markets because of their superior container port facilities. These countries include the USA, China, Hong Kong, Singapore, Japan, Taiwan, Korea, Italy, the United Kingdom (UK), Australia, Denmark, and most advanced European Union (EU) members. South Asian countries lie below the fitted curve. Consequently,

1 An earlier version of the paper was presented at the First Northeast Asia Logistics Conference, held at the Inha University, South Korea, 27-28 April 2004. We are deeply indebted to Dr. Andy Banerjee, NERA, USA for his comments on an earlier draft. The usual disclaimers apply.

- Research and Information System for the Non-Aligned and Other Developing Countries (RIS), Zone 4B, India Habitat Centre, Lodi Road. New Delhi 110 003, India. E-mail: Prabirde@hotmail.com, prabirde@sify.com

* Division of Economics and International Trade, Chosun University, 375 Seosuk-dong, Gwangju City 501-759, South Korea, E-mail: nkpark@mail.chosun.ac.kr 
economies with fewer political barriers to trade can enjoy greater returns on container port investments than those with a closed political system and poor port facilities. On these grounds, accession to the World Trade Organization (WTO) may be limited value if port services are too weak to support the trade growth.

Figure 1. Potential Contribution of Openness to Container Port Traffic

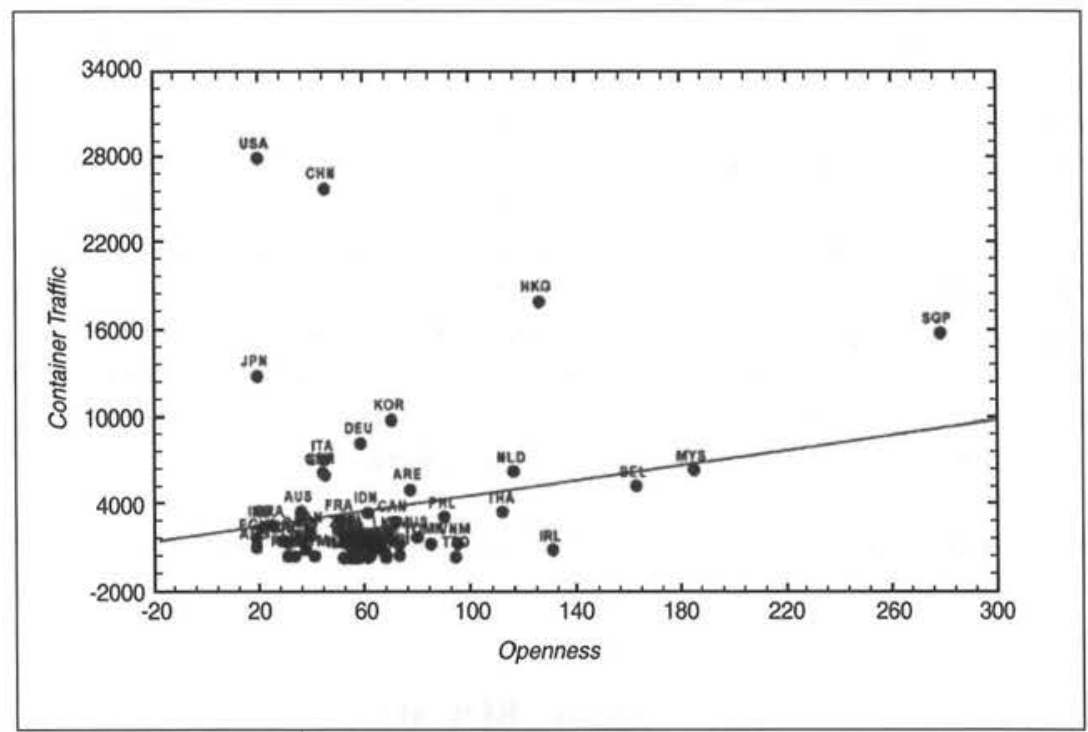

Notes: 1. Openness considers trade as percentage of GDP; 2. Openness and container traffic are taken for the year 2001 for 65 countries. 3 . Container traffic is taken in ' 000 TEUs.

Source: De (2003)

Figure 1 also suggests two additional correlates, which are quite relevant to East Asian container port system: openness and container traffic. The economies located above the fitted curve enjoy higher incomes than those below the fitted curve, and their exports, in general, are high-technology manufactures, which themselves generate substantial container traffic. Causality probably runs both ways. Economies like those of Japan, South Korea, Singapore, and Hong Kong have grown rich, as least in part, because of past investments in superior logistics, especially in ports. Meanwhile, Mongolia, Lao PDR, Cambodia, and Vietnam still suffer from poor port facilities. Countries that are outward-oriented with modern port facilities (China, Singapore, Korea, Japan, Hong Kong) will reap[PD1] more benefits from the globalized world[PD2] than countries those are less open and equipped with relatively poor port facilities (Vietnam). Therefore, the establishment and existence of well-functioning and efficient container port facilities are essential for economic development and growth.

Since the mid-1980s most countries have embarked on port reform. Some leading container ports, notably Singapore, Hong Kong and Rotterdam, have been privatized 
and, with the exception of US container ports that opted for slow commercialization, all other major container ports in the developed world have set in place a reformed model. Generally, the objective of port reform in most of the countries has been to improve performance and efficiency by distancing government from day-to-day operations, which was seen to be the cause of poor port performance.

Undoubtedly, reform has improved port performance, but dissatisfaction persists over the various reform models that have been applied in establishing competition in the port sector (Hirst, 2000; Ghosh and De, 2000; De and Ghosh, 2002). Clearly, the objective has not been met, and naturally political input continues to impede commercial objectives. A few giant ports are invading each other's market with, or without, collusive arrangements. This phenomenon is working against the competitive nature of the market and the globalisation process (Trujillo and Serebrisky, 2003).

While Hirst (2000) and Everett (2002) argue that political interference is the cause of port inefficiency, this is a somewhat erroneous and myopic view. After initiating the reform process since the 1980 s the port system finds itself working against competitive forces. Consequently, it is very difficult to say whether political interference is the cause of port inefficiency or it is an effect of anti-competitive forces. The more container traffic is concentrated in the hands of a few ports, the more inequality there is, and the larger the shares of the largest terminal operator in the container ports, the more concentration there is in the port system. The rise in concentration over a long period of time generates anti-competitive forces both between and within countries (Tschoegl, 1982).

The anti-competitive behaviour of terminal operators has already become an important issue in the post-reform period. Liner companies have become larger as a result of mergers and acquisitions, and global terminal operators have emerged to capitalize on investment opportunities driven by port privatization. ' Today, the world's top ten carriers have nearly 50 per cent of the world's carrying capacity expressed in TEUs (twenty equivalent units), while the world's top ten terminal operators, including HPH, PSA, APM Terminals, P\&O Ports, Maersk, Evergreen, Eurogate, SSA, West Port, and CSX World Terminals, handled about 45 per cent of world's port container volume (UNCTAD, 2003). The emerging dominance of these firms, at least in the carrier industry, has not gone unnoticed because their anti-competitive immunity is being debated and challenged.

While the concentration phenomenon is characteristic of both terminal operators and carriers, one can also see the rise in concentration among ports in the global maritime community. Ports (and to some extent maritime countries) follow strategies to control the volume of container traffic (De and Park, 2003b). These countries are highly dependable on single port, heavily reliant on transhipment traffic, and ideally placed on 'East-West' shipping corridor (De and Park, 2003a, 2003b). The thematic view of above proposition is explained in Figure 2. Countries $C_{1}$ to $C_{5}$, which are placed on East-West Shipping corridor (EW) in Figure 2, have a larger share of world container volume than those that are placed elsewhere in the diagram.

\footnotetext{
1 For a good discussion of concentration trends, see Hoffman $(1998,2002)$.
} 
Figure 2. Thematic View of Rising Concentration of Single-Port Dependence Countries

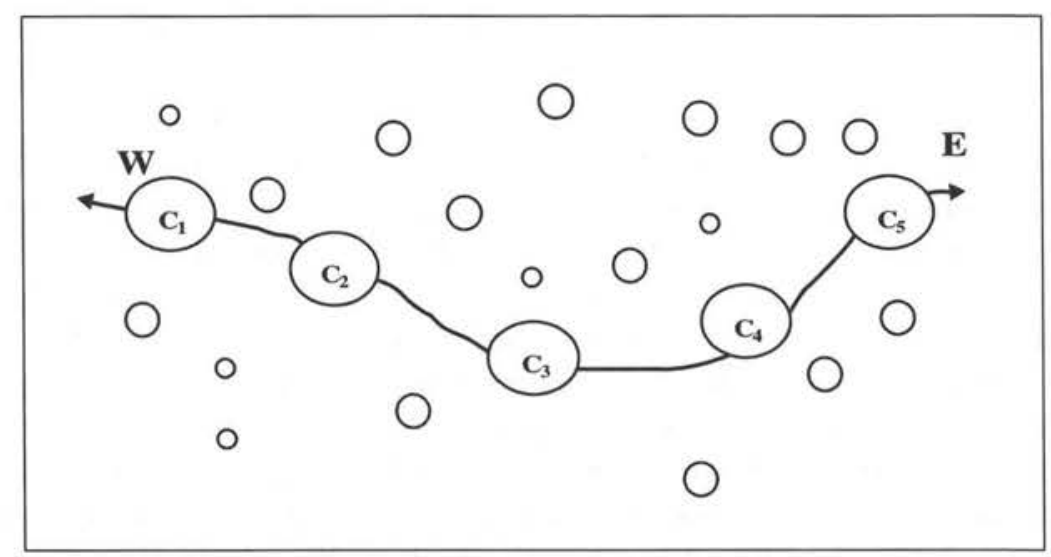

Source: Drawn by Authors

The rising dominance of single-port dependent countries in the container segment has not attracted much attention. Therefore, the world container system is now faced with two types of anti-competitive forces: one is due to emergence of highly concentrated single-port dependent countries; and the other stems from the global dominance of terminal operators. In both cases, terminal operators and ports exercise considerable market power in pricing their services. Some studies, notably Kent and Ashar (2001) and Kent (2002), have dealt with the anti-competitive behaviour of terminal operators, but they have equally ignored the anti-competitive behaviour of port authorities and maritime countries.

A port grows by virtue of the trade it attracts. We see a picture of general growth of container traffic among East Asian ports, particularly since the mid-1980s. In an open economy, the growth of large ports may contribute to the increasing concentration of a cargo flows through the penetration of the hinterlands of other ports or through internal growth. This is also very true for maritime countries with highly concentrated port activity. According to Tschoegl (1982), concentration is a social issue because concentration is conducive to both cartelistic and oligopolistic behaviour and alters the distribution of power with a country's economic structure. In the presence of high concentration, a relatively small group of ports run simultaneously across the system, employing similar methods and conventions of analysis and behaviour. Such a practice may help to determine, in part, the port tariff and service manipulation among key ports in the system. Furthermore, during economic downturns and a fall in trade, a decline in traffic and deterioration of capital position of some ports in the system may develop into a major port sector crisis. The larger the port concentration, the larger is the potential severity of any loss in international trade. Thus, the effects of public policies on competitive relationships in ports and the efficiency of their performances have become more important as competition among alternative traffic routes has increased. Antitrust behaviour is likely to become a more prominent issue in postglobalisation environments because they are characterized as having highly 
concentrated markets. The extent of competition that emerges defines the degree to which operators would be regulated in light of antitrust concerns. While monitoring the antitrust behaviour of terminal operators, there is also need to monitor the competitive environment in the global maritime community.

Given this overview, this paper investigates the formal properties of the rising concentration within the container port system with special reference to countries in East Asia. The next section focuses on the data and measurement of concentration within the port system. Then the empirical results are discussed, followed by an investigation into the level of world container port system concentration. The rise of East Asia in world container traffic is discussed before conclusions are drawn.

\section{DATA AND METHODOLOGY}

The main resources of this study are taken from various issues of Containerisation International Yearbook. This data set is supplemented by several publications of the United Nation Conference of Trade and Development (UNCTAD), Geneva; the International Association of Ports and Harbours (IAPH), Tokyo; and the International Navigation Association (PIANC), Brussels.

To discover differences in container port concentration 'between' and 'within' economic blocs, we have classified countries in three categories: category I covers five regions[PD3] - South Asia, East Asia, the European Union (United Kingdom, Germany, France, Holland, Italy, Spain, Belgium, Portugal, Greece, and Denmark), USA, and rest of the world; category $I I$ considers individual South Asian and East Asian countries, and the EU, USA and rest of the world separately; and category III covers individual East Asian countries only. Table 1 highlights this categorisation. Treating some selected Southeast Asian countries as East Asian countries eases comprehension.

Table 1. Classification of Countries

\begin{tabular}{l|l}
\hline Category & \multicolumn{1}{c}{ Countries } \\
\hline \hline Category I & East Asia, South Asia, USA, EU, Others \\
\hline Category II & Hong Kong, Singapore, Japan, Taiwan, Korea, China, \\
& Malaysia, Indonesia, Philippines, Thailand, India, \\
& Sri Lanka, Pakistan, Bangladesh, USA, EU, Others \\
\hline Category III & $\begin{array}{l}\text { Hong Kong, Singapore, Japan, Taiwan, Korea, China, } \\
\text { Malaysia, Indonesia, Philippines, Thailand }\end{array}$ \\
\hline
\end{tabular}

Notes: 1. EU refers United Kingdom, Germany, France, Holland, Italy, Spain, Belgium, Portugal, Greece, and Denmark. 2. South Asia counts India, Bangladesh and Pakistan. 3. East Asia considers Hong Kong, Singapore, Japan, Taiwan, Korea, China Malaysia, Indonesia, Philippines, and Thailand. 
As the framework demonstrates, to assess changes in port system concentration, we have used (1) the Gini Coefficient, a widely used index that measures inequality, ${ }^{2}$ and (2) the Herfindahl-Hirschmann Index that measures the degree of market concentration (Herfindahl, 1950) ${ }^{3}$. Since there are many different measures of dispersion, and no particular reason to favour one over another, we sought to assess the degree of concentration system using both the Gini Coefficient and the Herfindahl-Hirschmann Index. ${ }^{4}$

The first measure is the Gini coefficient $(\mathrm{G})$ :

$$
G=0.5 \sum_{i=1}^{n}\left|X_{i}-Y_{i}\right|
$$

Where $n$ is countries, $X_{i}$ is the volume of container traffic in percent of the ith country and $Y_{i}$ is the expected percentage of container traffic if the distribution were perfectly uniform - that is, $Y_{i}=1 / n$. The Gini coefficient ranges from zero (perfect even distribution) to one (perfectly concentrated distribution): the more equal the sector shares, the more diversified nature of the economic system (here the container port system). This is a common measure of sectoral and regional concentration in the economic geography literature. ${ }^{5}$

The second measure of concentration is the Herfindahl-Hirschmann Index (HHI). This measure of the degree of market concentration has been normalized to obtain values ranking from 0 to 1 (maximum concentration), according to the following formula.

$$
H_{i t}=\sum_{i=1}^{n}\left(\frac{x_{i t}}{X_{i t}}\right)^{2}
$$

where $H_{i t}$ is value of concentration index for country $i$ for the year $t, x_{i t}$ denotes the container traffic of country $i$ in year $t, X_{i t}$ means total world container port traffic in year $t$.

The cross-country measurements of concentration through $G$ and $H$ provide some preliminary idea about the nature and trend of the inter-country competitive

2 The Gini coefficient was developed by the Italian statistician Corrado Gini. Initially, it was developed to measure the degree of concentration (or inequality) in income distribution.

${ }^{3}$ The HHI's development is attributed to two noted economists, namely, Orris C. Herfindahl, who developed it as part of his doctoral dissertation, "Concentration in the Steel Industry" at Columbia University, New York, in 1950, as well as noted economist Albert O. Hirschman, who used it in his research in industry concentration in 1950. There are several complex models available that are intended to reflect market behaviour (e.g. Cournot and Bertrand models and their derivatives), but their roots are embedded in the general concepts of market concentration and firm dominance. See, Cournot (1927) and Bertrand (1883).

4 One can also take max-min spread, log-variance of sector shares, entropy etc. to measure the concentration system.

5 See, for instance, Krugman (1991), who used "locational Ginis" to measure the geographic concentration of given sectors across locations. In contrast, we compute "sectoral Ginis", measuring the concentration of container port system across the globe. 
environment in relation to container port traffic. To gauge the level of concentration, we have carried out three non-parametric tests, though these do not directly relate to the growth of the container traffic of maritime countries. These tests are: (i) Kendall's coefficient of concordance $(W)$, (ii) Spearman's rank correlation $(R)$, and (iii) coefficient of variation $(\mathrm{CV})$. The third test involves a cardinal measure while the first two are ordinal measures. Hence, any conclusion derived from the two ordinal measures may not necessarily mean either narrowing down or a widening of the real level of concentration. ${ }^{6}$ [PD4]

\section{Kendall's Coefficient of Concordance (W)}

$$
W=s /(1 / 12) \cdot k^{2} \cdot\left(N^{3}-N\right)
$$

where, $\mathrm{s}=$ sum of squares of the observed deviations from the mean of $R_{j}$ (i.e., $s=$ $\sum\left(R_{j}-R / N\right)^{2}$, where, $R_{j}$ is the rank of the jth country in a particular year, $k=$ number of years and $N=$ number of countries, $(1 / 12) \cdot k^{2} \cdot\left(N^{3}-N\right)=$ Maximum possible sum of the squared deviations, i.e., the sums which would occur with perfect agreement among $k$ rankings.

The test of significance of $W$, i.e., $\chi^{2}$ value associated with a particular value of $W$ can be calculated as follows.

$$
\chi^{2}=s /(1 / 12) \cdot k \cdot N \cdot(N+1)=k \cdot(N-1) \cdot W
$$

Thus, the value of $\chi^{2}$ can be found out with $d f=N-1$ to determine the probability associated with the occurrence under $\mathrm{HO}$ of any value as large as an observed w. If the value of $\chi^{2}$ equals or exceeds that shown in the standard table for critical value of $\chi^{2}$ for a particular level of significance and a particular value of $d f=N-1$, then the null hypothesis that the $k$ sets of rankings are unrelated may be rejected at that level of significance. The value of $W$ ranges from zero to one. If $W=0$, it means that there is no concordance among the countries between the particular pair of years. That is, the countries have completely changed their relative positions. If $W=1$, the reverse is true (i.e., there has been perfect concordance among the countries). That is, no change has taken place in the relative positions of the countries. Interestingly, $w$ bears a linear relationship with $\mathrm{r}_{\mathrm{s}}$ but seems to bear no orderly relation with Kendall's Tau (Siegel, 1956).

\section{Spearman's Rank Correlation Coefficient $(R)$}

Of all the statistics based on ranks, the Spearman's rank correlation coefficient, $r$, was the earliest, and is still perhaps the best known. The coefficient is a measure of association, which requires that both variables be measured in at least an ordinal scale so that the countries may be ranked in two ordered series.

${ }^{6}$ In terms of the standard convergence literature, if the $C V$ declines over time, the container handling countries are said to satisfy the condition of sigma-convergence (Barro and Sala-i-Martin, 1995). 


$$
R=1-\left(6 \sum_{i=1}^{N} d_{i}^{2}\right) / N^{3}-N
$$

where $d_{i}=$ difference between two series of rankings. When $N$ is large, the significance of an obtained $\mathrm{r}_{\mathrm{s}}$ under the null hypothesis may be tested by: $t=R \sqrt{ }(N$ $2) /\left(1-R^{2}\right)$, where $d f=N-2$. Thus, the associated probability under $H_{0}$ (the null hypothesis) of any value as extreme as an observed value of $R$ can be determined.

\section{COMPETITIVE ENVIRONMENT IN CONTAINER PORT SYSTEM: AN ASSESSMENT}

Table 2 presents the value of the Gini coefficients and the Herfindahl-Hirschmann indices under three combinations of the dataset as described in Table 1. The major findings are as follows.

Firstly, in terms of Gini co-efficient, concentration within the container port system increased from 0.189 in 1985 to 0.204 in 1990, then it increased from 0.242 in 1995 to 0.261 in 2000 for all groups falling under Category I. According to the HerfindahlHirschmann Index, there has been a continuous rise of concentration since 1985. Interestingly, the concentration measured through $G$ and $H$ is consistent. Results of these three measures directly indicate increasing degree of concentration that has occurred among the economic groups of category I.

Table 2. Container Port System Concentration

\begin{tabular}{l|c|c|c|c}
\hline Category & Year & $\mathbf{G}^{\mathbf{1}}$ & $\mathbf{L}^{2}$ & $\mathbf{H}^{3}$ \\
\hline \hline Category I & 1985 & 0.189 & 0.243 & 0.248 \\
& 1990 & 0.204 & 0.301 & 0.263 \\
& 1995 & 0.242 & 0.357 & 0.291 \\
& 2000 & 0.261 & 0.370 & 0.292 \\
\hline Category II & 1985 & 0.568 & 0.681 & 0.183 \\
& 1990 & 0.478 & 0.608 & 0.148 \\
& 1995 & 0.443 & 0.545 & 0.128 \\
& 2000 & 0.426 & 0.513 & 0.130 \\
\hline Category III & 1985 & 0.390 & 0.504 & 0.199 \\
& 1990 & 0.351 & 0.406 & 0.158 \\
& 1995 & 0.316 & 0.325 & 0.148 \\
& 2000 & 0.279 & 0.190 & 0.136 \\
\hline
\end{tabular}

Notes : $1 . G$ refers to Gini coefficients.

2. $L$ refers to Lorenz ratios. Relationship between $G$ and $\mathrm{L}$ is simple. The $G$ is equal to the ratio of the area between the Lorenz curve and the diagonal line, relative to the maximum possible area (the entire right angle formed by the bottom and right axes and the diagonal.

3. $H$ means Herfindahl-Hirschmann index 
Second, we have found opposite the result of $G$ and $H$ in the case of category II compared with category I regions. Here, port system concentration, measured by $G$, has fallen from 0.568 in 1985 to 0.478 in 1990 to 0.443 in 1995 to 0.426 in 2000 . Also values of $\mathrm{H}$ have fallen consistently since 1985 except 2000 (although this rise remained at a lower level compared to 1985). Naturally, therefore, results are quite consistent (i.e., the system has been diversified in tandem with the fall of concentration). Obviously, inclusion of individual countries from South and East Asia group in the analysing set has changed the direction. ${ }^{7}$

Finally, we have found similarities in the results between category II and category III. Here values of $G$ and $H$ indicate a clear tendency of equalisation of concentration with the container port system over time. One plausible reason for this observation may be that the share of most of the East Asian countries in world total container traffic has increased and more ports have started handling containers.

Having seen the results of Gini co-efficient and Herfindahl-Hirschmann Index, let's briefly analyse the results of $W, R$ and $C V$.

Table 3 (a). Spearman's Rank Correlation $(R)$ and Kendall's Coefficient of Concordance $(W)$

\begin{tabular}{l|c|c|c|c|c}
\hline Category & Year & $\begin{array}{c}\text { Spearman } \\
\boldsymbol{R}\end{array}$ & $\begin{array}{c}\mathbf{t} \\
\text { Value }\end{array}$ & $\begin{array}{c}\text { Kendall's } \\
\boldsymbol{W}\end{array}$ & $\begin{array}{c}\chi^{2} \\
\text { Value }\end{array}$ \\
\hline \hline Category I & 1985 & & & & \\
& 1990 & 0.900 & 3.576 & 1.000 & 9.000 \\
& 1995 & 1.000 & & 0.967 & 13.533 \\
& 1996 & 1.000 & & 0.962 & 18.287 \\
& 1997 & 1.000 & & 0.960 & 23.040 \\
& 1998 & 1.000 & & 0.958 & 27.792 \\
& 1999 & 1.000 & & 0.957 & 32.543 \\
& 2000 & 1.000 & & 0.956 & 37.294 \\
\hline Category II & 1985 & & & & \\
& 1990 & 0.990 & 27.455 & 0.995 & 32.838 \\
& 1995 & 0.936 & 10.323 & 0.975 & 48.775 \\
& 1996 & 0.990 & 27.455 & 0.979 & 65.604 \\
& 1997 & 0.993 & 31.761 & 0.982 & 82.476 \\
& 1998 & 0.995 & 38.971 & 0.984 & 99.391 \\
& 1999 & 0.995 & 38.971 & 0.986 & 116.306 \\
& 2000 & 0.988 & 24.511 & 0.986 & 133.097 \\
\hline Category III & 1985 & & & & \\
& 1990 & 0.976 & 12.610 & 0.988 & 18.772 \\
& 1995 & 0.697 & 2.749 & 0.891 & 25.839 \\
& 1996 & 0.952 & 8.749 & 0.906 & 35.344 \\
& 1997 & 0.964 & 10.200 & 0.918 & 44.972 \\
& 1998 & 0.976 & 12.610 & 0.928 & 54.723 \\
& 1999 & 0.976 & 12.610 & 0.934 & 64.476 \\
& 2000 & 0.939 & 7.750 & 0.935 & 73.869 \\
\hline
\end{tabular}

Note: Fisher transformation of Spearman $R$ was done based on $Z^{\prime}=\frac{1}{2} \ln (1+x / 1-x)$.

This transformation produces a function that is normally distributed rather than skewed.

7 In another study, taking container throughout of 185 countries and using Herfindahl-Hirschmann Index, Jung (2003) has observed rising concentration in world container port system between 1990 and 1995 and a trend towards deconcentration between 1995 and 2000. 


\section{Spearman's Rank Correlation (R) and Kendall's Coefficient of Concordance (W)}

The values of $R$ and $W$ with the corresponding t-statistics and chi-squares from 1985 to 2000 are presented in Table 3(a). As evident from these values, the value of $R$ has been static all through these years with some minor fluctuations starting from $0.990(t=27.455)$ in 1990 to $0.988(t=24.511)$ in 2000 in category II. Interestingly, in the case of category III, we have seen fall of $R$ during 1985-2000. In 1990, $R$ was $0.976(t=12.610)$, which became $0.939(t=7.750)$ in 2000. It has never gone below 0.90 in category II, the lowest value of 0.936 having been recorded in 1995 . However, the same has gone below 0.70 in category III. The values of the t-statistics ensure that the null hypothesis (that there is stability among the relative rankings of the countries in terms of container concentration over time) is rejected at the 1 per cent level of significance. ${ }^{8}$ Thus, the tendency of relative fixation of the countries in their respective positions is a bit subdued in category II whereas the same for East Asian countries (in category III) has been reduced. On the other hand, the value of W has also been found decreasing in both the categories, though values have found to be very high all through these years. It has reduced to 0.986 in 2000 from 0.995 in 1990 in category II and 0.935 in 2000 from 0.988 in 1990 in category III. Moreover, the values of the corresponding $\chi^{2}$ dictate that the null hypothesis of concordance among the countries is rejected at 1 per cent level of significance over the period of our study. Thus, it is clear from above findings that the relative position of East Asian countries has been changing in terms of container throughput.

Contrary to above findings, we have found just opposite result in case of category I. High values of $\mathrm{R}$ and $\mathrm{W}$ in all the cases except 1990 indicates very high degree of stickiness in the relative rankings of the East and South Asian blocs in terms of container throughput.

\footnotetext{
${ }^{8}$ Although the t-statistics that we have reported here test the null hypothesis of independence (no correlation) among the ranked series, to examine the stability among the relative rankings, we also test the hypothesis of equal correlations among different pairs of ranked series through Fisher, transforming the correlation coefficients into $\mathrm{z}$-statistics and then computing a composite $\mathrm{z}$ test statistic based on the series. For further details of the technique, one can refer to Sheshkin (2000).
} 
Table 3(b). Mean, Standard Deviation and Coefficient of Variation $(\mathrm{CV})$

\begin{tabular}{l|r|r|r|l}
\hline Category & Year & \multicolumn{1}{c|}{ Mean } & \multicolumn{1}{c}{ SD } & CV \\
\hline \hline Category I & 1985 & 11180600.00 & 5497514.26 & 0.492 \\
& 1990 & 17119400.00 & 9611381.85 & 0.561 \\
& 1995 & 27447713.80 & 18478205.85 & 0.673 \\
& 1996 & 30150511.60 & 19783588.61 & 0.656 \\
& 1997 & 33046805.60 & 20167123.13 & 0.610 \\
& 1998 & 36396595.20 & 22710074.44 & 0.624 \\
& 1999 & 39052291.60 & 25980701.32 & 0.665 \\
& 2000 & 45058805.00 & 30623899.27 & 0.680 \\
\hline Category II & 1985 & 3288411.76 & 4782968.58 & 1.454 \\
& 1990 & 5035117.65 & 6208758.52 & 1.233 \\
& 1995 & 8072857.00 & 8784397.35 & 1.088 \\
& 1996 & 8867797.53 & 9701259.56 & 1.094 \\
& 1997 & 9719648.71 & 11238101.32 & 1.156 \\
& 1998 & 10704880.94 & 12401651.40 & 1.159 \\
& 1999 & 11485968.12 & 12609358.76 & 1.098 \\
& 2000 & 13252589.71 & 14600933.67 & 1.102 \\
\hline Category III & 1985 & 1592800.00 & 1586542.01 & 0.996 \\
& 1990 & 3158200.00 & 2415140.36 & 0.765 \\
& 1995 & 5980666.80 & 4141930.16 & 0.693 \\
& 1996 & 6452389.20 & 4366322.19 & 0.677 \\
& 1997 & 6618275.40 & 4616983.26 & 0.698 \\
& 1998 & 7340885.60 & 4734011.21 & 0.645 \\
& 1999 & 8374772.20 & 5222954.78 & 0.624 \\
& 2000 & 9750575.70 & 5870602.92 & 0.602 \\
\hline
\end{tabular}

Let us now see what has happened to the relative positions of the countries in terms of actual level of container throughput. The coefficient of variation $(\mathrm{CV})$ measures the dispersion of container throughput at a point in time. Here, also, one has the freedom of judging the movement of this dispersion over time.

Figure 3. Co-efficient of Variations

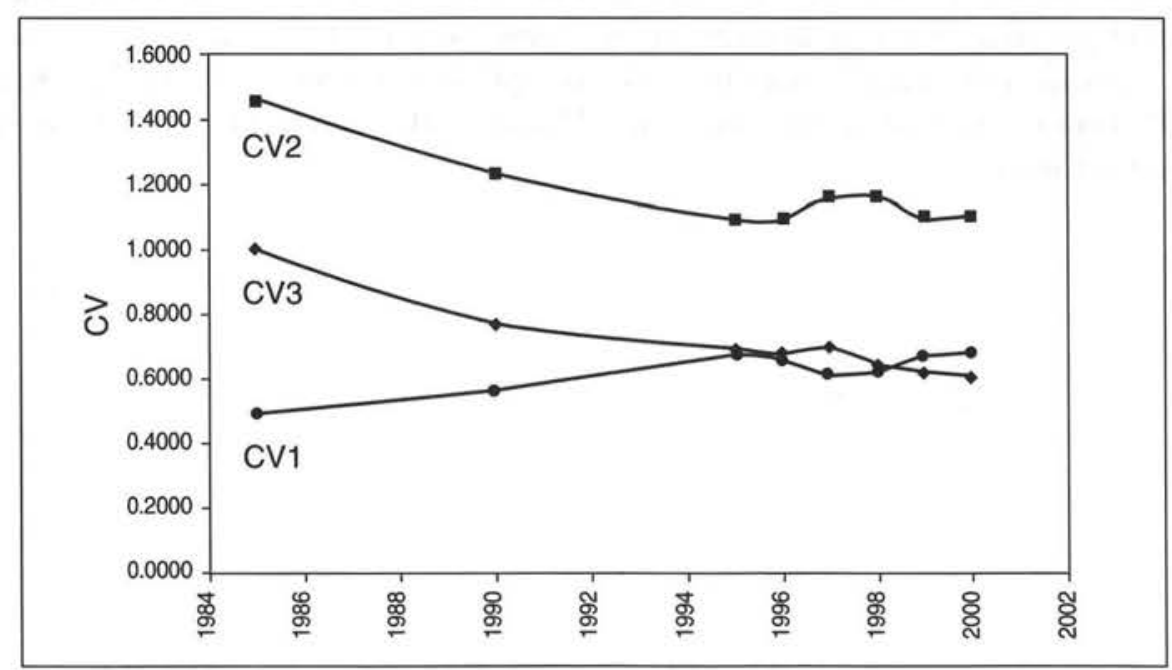




\section{Coefficient of Variation (CV)}

The values of $C V$ along with mean and standard deviation from 1985 to 2000 are presented in Table 3(b) for all three categories and the corresponding fitted curves are given in Figure 3. Here, the value of $C V$ has not only been found to be low but it has also been falling during this period in categories of II and III. What is most interesting to observe is that the trend of $C V$ has recorded a significant downward shift in the entire period for both categories II and III, although this has somewhat subdued in category I. As evident from the values of $C V$, the rate of growth of disparity in terms of container throughout among the countries in categories II and III has declined during 1985-2000. However, given the overall goodness of fit, there is no immediate possibility for the $C V$ to go up to the initial level. The standard convergence literature states that although differences in technology, preferences and institutions do exist across regions within countries, these differences are likely to be smaller than those across countries. Hence, there appears to be a tendency towards container port system convergence among East Asian countries whereas economic blocs, as indicated in category I, show symptoms towards container port system divergence.

\section{INEQUALITY-DEVELOPMENT RELATIONSHIP WITHIN THE EAST ASIAN CONTAINER PORT SYSTEM}

After the Second World War East Asia (Japan, China, Singapore, Taiwan, South Korea, the Philippines, Thailand, Indonesia, Malaysia, and Hong Kong) has enjoyed a remarkable record of high and sustained economic growth which grew faster than all other regions of the world. East Asia's remarkable economic prosperity can be seen from its real gross domestic product (GDP) growth rate. During the period 1990-2000, East Asia has experienced average real GDP growth of 9.5 percent per annum compared to an average 4.0 percent worldwide, 2.2 percent in Japan, 2.6 percent in the US, and 2.3 percent in EU. This remarkable economic growth in East Asian countries has been spread over four decades starting with Japan in the 1960s when it became the focus of global attention as an emerging economic power catching up with the US and EU. Subsequently, Japan's rapid progress has spread to neighbouring Taiwan, Korea, the Philippines, Indonesia, Singapore, and Thailand. This spectacular growth has now spread to China. 
Table 4. East Asian Hub Ports and Hinterland

\begin{tabular}{l|c|c|c|l|l}
\hline Port & \multicolumn{2}{|c|}{$\begin{array}{c}\text { Throughout } \\
\text { (Million TEU) }\end{array}$} & $\begin{array}{l}\text { Transhipment } \\
\text { Traffic (\%) }\end{array}$ & \multicolumn{2}{|c}{ Hinterland } \\
\cline { 2 - 6 } & $\mathbf{1 9 9 0}$ & $\mathbf{2 0 0 0}$ & $\mathbf{2 0 0 0}$ & \multicolumn{1}{|c}{$\mathbf{1 9 9 0}$} & \multicolumn{1}{|c}{$\mathbf{2 0 0 0}$} \\
\hline \hline Hong Kong & 5.10 & 18.10 & 30 & $\begin{array}{l}\text { China, North } \\
\text { America, } \\
\text { Japan }\end{array}$ & $\begin{array}{l}\text { North America, } \\
\text { Southeast America, } \\
\text { Europe, China, Japan, } \\
\text { Southeast Asia }\end{array}$ \\
\hline Singapore & 5.22 & 17.04 & 96 & $\begin{array}{l}\text { Southeast Asia, } \\
\text { South Asia, } \\
\text { Europe, North } \\
\text { America, China, } \\
\text { Middle East }\end{array}$ & $\begin{array}{l}\text { North America, Europe, } \\
\text { China, Japan, Southeast } \\
\text { Asia, South Asia, } \\
\text { Australia }\end{array}$ \\
\hline Busan & 2.35 & 7.54 & 36 & $\begin{array}{l}\text { China, Korea, } \\
\text { Japan }\end{array}$ & $\begin{array}{l}\text { North America, } \\
\text { Southeast America, } \\
\text { Eastern Russia, } \\
\text { Northeast China, Japan, } \\
\text { East Asia }\end{array}$ \\
\hline Kaohsiung & 3.50 & 7.43 & 52 & $\begin{array}{l}\text { China, Taiwan, } \\
\text { East Asia }\end{array}$ & $\begin{array}{l}\text { North America, } \\
\text { Southeast America, } \\
\text { China, Japan, Southeast } \\
\text { Asia }\end{array}$ \\
\hline Shanghai & 0.55 & 5.75 & 1 & $\begin{array}{l}\text { North America, Eastern } \\
\text { Russia, China, Japan, } \\
\text { Southeast Asia }\end{array}$ \\
\hline
\end{tabular}

Note: 1 . Share in total container throughout.

Source: Containerisation International, Various Issues

In turn, volumes of shipping have risen dramatically, generating a large concentration of container tonnage in East Asia. For almost a decade more than half the ports in the world's ports top 10 container ports have been from East Asia. In 2000, the container throughput of four hub ports in the East Asia (Hong Kong, Singapore, Kaohsiung, and Busan) accounted for almost one-quarter of the global total container trade-a reflection of the extension of their hinterlands. Table 4 shows container throughout and the hinterlands of Hong Kong, Singapore, Kaohsiung, Shanghai, and Busan for 1990 and 2000. Rising container throughput has been reflected in growing hinterlands being served by these five ports in 2000. What is more interesting, Shanghai surpassed Rotterdam, joining Hong Kong, Singapore, Kaohsiung, and Busan among the world's top five in 2001. The high economic growth of East Asia resulted in international trade experiencing a boom. This has greatly changed the world's shipping environment. The huge container traffic generated in East Asia has reshaped the international shipping itineraries favouring the countries in this region.

Table 5 focuses on how the container-shipping itinerary of this region has changed between 1990 and 2000. In 1990, the world's top trade line-the Trans-Pacific (Asia/North America) service handled 5.34 million TEUs, in 2000, but by 2001 the traffic volume reached 12 million TEUs, an increase of more than 100 per cent. 
Conversely the container volume in the Asia/Europe service more than doubled from 2.9 million TEUs to 7 million TEUs. In turn, due to this large traffic, direct calls to most East Asian ports increased remarkably, thereby reducing inter-port disparity in terms of accessibility.

Table 5. World Container Traffic Flow

Year: 1990

\begin{tabular}{l|c|c|c}
\hline & Europe & North America & Asia \\
\hline \hline Europe & 4.55 & 3.05 & 2.89 \\
\hline North America & 3.05 & & 5.34 \\
\hline Asia & 2.89 & 5.34 & 3.50 \\
\hline
\end{tabular}

Year: 2000

\begin{tabular}{l|c|c|c}
\hline & Europe & North America & Asia \\
\hline \hline Europe & 6.50 & 4.50 & 7.00 \\
\hline North America & 4.50 & & 12.00 \\
\hline Asia & 7.00 & 12.00 & 8.50 \\
\hline
\end{tabular}

Source: Containerisation International, Various Issues

In 1990, the container traffic volume handled in Hong Kong, Singapore, Taiwan, and Korea, accounted for 15 percent of the world's total container traffic volumes. In comparison, during the same year, the container traffic volume handled in TransPacific service was 5.34 million TEUs and the volume in intra-European service was 4.55 million TEUs, accounting for 22.8 percent and 19.4 percent of the world's total container traffic, respectively.

Table 6. Container Port System Concentration: $\mathrm{H}$ Values

(a) Category I

\begin{tabular}{l|c|c|c|c|c|c|c|c}
\hline Economic Blocs & $\mathbf{1 9 8 5}$ & $\mathbf{1 9 9 0}$ & $\mathbf{1 9 9 5}$ & $\mathbf{1 9 9 6}$ & $\mathbf{1 9 9 7}$ & $\mathbf{1 9 9 8}$ & $\mathbf{1 9 9 9}$ & $\mathbf{2 0 0 0}$ \\
\hline \hline East Asia & 0.0812 & 0.1361 & 0.1899 & 0.1832 & 0.1604 & 0.1627 & 0.1840 & 0.1873 \\
\hline South Asia & 0.0001 & 0.0003 & 0.0005 & 0.0006 & 0.0007 & 0.0006 & 0.0006 & 0.0005 \\
\hline USA & 0.0426 & 0.0317 & 0.0194 & 0.0209 & 0.0207 & 0.0176 & 0.0166 & 0.0147 \\
\hline EU & 0.0699 & 0.0530 & 0.0383 & 0.0366 & 0.0403 & 0.0414 & 0.0418 & 0.0380 \\
\hline Others & 0.0546 & 0.0419 & 0.0426 & 0.0448 & 0.0524 & 0.0555 & 0.0455 & 0.0519 \\
\hline World & 0.2484 & 0.2630 & 0.2906 & 0.2861 & 0.2745 & 0.2779 & 0.2885 & 0.2924 \\
\hline
\end{tabular}


(b) Category II

\begin{tabular}{l|c|c|c|c|c|c|c|c}
\hline Countries & $\mathbf{1 9 8 5}$ & $\mathbf{1 9 9 0}$ & $\mathbf{1 9 9 5}$ & $\mathbf{1 9 9 6}$ & $\mathbf{1 9 9 7}$ & $\mathbf{1 9 9 8}$ & $\mathbf{1 9 9 9}$ & $\mathbf{2 0 0 0}$ \\
\hline \hline Hong Kong & 0.001677 & 0.003551 & 0.008362 & 0.007972 & 0.007772 & 0.006421 & 0.006892 & 0.006454 \\
\hline Singapore & 0.000924 & 0.003725 & 0.007450 & 0.007372 & 0.007318 & 0.006917 & 0.006668 & 0.005758 \\
\hline Japan & 0.009739 & 0.008639 & 0.005970 & 0.005356 & 0.004345 & 0.003344 & 0.003843 & 0.003655 \\
\hline Taiwan & 0.003026 & 0.004055 & 0.003271 & 0.002723 & 0.001187 & 0.001187 & 0.001280 & 0.001086 \\
\hline Korea & 0.000497 & 0.000752 & 0.001076 & 0.001134 & 0.001187 & 0.001260 & 0.001290 & 0.001434 \\
\hline China & 0.000064 & 0.000198 & 0.001162 & 0.001301 & 0.001189 & 0.003096 & 0.004557 & 0.005953 \\
\hline Malaysia & 0.000048 & 0.000108 & 0.000229 & 0.000286 & 0.000324 & 0.000277 & 0.000408 & 0.000419 \\
\hline Indonesia & 0.000017 & 0.000117 & 0.000223 & 0.000137 & 0.000135 & 0.000147 & 0.000186 & 0.000294 \\
\hline Philippines & 0.000130 & 0.000271 & 0.000152 & 0.000241 & 0.000230 & 0.000180 & 0.000208 & 0.000256 \\
\hline Thailand & 0.000051 & 0.000159 & 0.000204 & 0.000185 & 0.000162 & 0.000210 & 0.000219 & 0.000210 \\
\hline India & 0.000020 & 0.000061 & 0.000098 & 0.000100 & 0.000119 & 0.000092 & 0.000100 & 0.000105 \\
\hline Sri Lanka & 0.000013 & 0.000041 & 0.000056 & 0.000081 & 0.000104 & 0.000089 & 0.000076 & 0.000059 \\
\hline Pakistan & 0.000003 & 0.000006 & 0.000016 & 0.000014 & 0.000009 & 0.000015 & 0.000013 & 0.000012 \\
\hline Bangladesh & 0.000001 & 0.000002 & 0.000003 & 0.000003 & 0.000003 & 0.000004 & 0.000004 & 0.000004 \\
\hline USA & 0.042561 & 0.031720 & 0.019377 & 0.020867 & 0.020674 & 0.017632 & 0.016610 & 0.014684 \\
\hline EU 10 & 0.069919 & 0.052952 & 0.038265 & 0.036619 & 0.040340 & 0.041427 & 0.041833 & 0.037955 \\
\hline Others & 0.054578 & 0.041908 & 0.042558 & 0.044832 & 0.052361 & 0.055475 & 0.045530 & 0.051884 \\
\hline World & 0.183267 & 0.148266 & 0.128473 & 0.129224 & 0.137462 & 0.137772 & 0.129716 & 0.130226 \\
\hline
\end{tabular}

(c) Category III

\begin{tabular}{l|c|c|c|c|c|c|c|c}
\hline Countries & $\mathbf{1 9 8 5}$ & $\mathbf{1 9 9 0}$ & $\mathbf{1 9 9 5}$ & $\mathbf{1 9 9 6}$ & $\mathbf{1 9 9 7}$ & $\mathbf{1 9 9 8}$ & $\mathbf{1 9 9 9}$ & $\mathbf{2 0 0 0}$ \\
\hline \hline Hong Kong & 0.0207 & 0.0261 & 0.0440 & 0.0435 & 0.0484 & 0.0395 & 0.0375 & 0.0345 \\
\hline Singapore & 0.0114 & 0.0274 & 0.0392 & 0.0402 & 0.0456 & 0.0425 & 0.0362 & 0.0307 \\
\hline Japan & 0.1200 & 0.0635 & 0.0314 & 0.0292 & 0.0271 & 0.0205 & 0.0209 & 0.0195 \\
\hline Taiwan & 0.0373 & 0.0298 & 0.0172 & 0.0149 & 0.0074 & 0.0073 & 0.0070 & 0.0058 \\
\hline Korea & 0.0061 & 0.0055 & 0.0057 & 0.0062 & 0.0074 & 0.0077 & 0.0070 & 0.0077 \\
\hline China & 0.0008 & 0.0015 & 0.0061 & 0.0071 & 0.0074 & 0.0190 & 0.0248 & 0.0318 \\
\hline Malaysia & 0.0006 & 0.0008 & 0.0012 & 0.0016 & 0.0020 & 0.0017 & 0.0022 & 0.0022 \\
\hline Indonesia & 0.0002 & 0.0009 & 0.0012 & 0.0007 & 0.0008 & 0.0009 & 0.0010 & 0.0016 \\
\hline Philippines & 0.0016 & 0.0020 & 0.0008 & 0.0013 & 0.0014 & 0.0011 & 0.0011 & 0.0014 \\
\hline Thailand & 0.0006 & 0.0012 & 0.0011 & 0.0010 & 0.0010 & 0.0013 & 0.0012 & 0.0011 \\
\hline Total & 0.1992 & 0.1585 & 0.1480 & 0.1458 & 0.1487 & 0.1416 & 0.1389 & 0.1362 \\
\hline
\end{tabular}

In 2000, the total world container traffic exceeded 225 million TEUs. Table 5 shows that container traffic handled in the intra-Asian service in 1990 was lower than that of Trans-Pacific and the intra-European services. By 2000, this had been reversed as the Intra-Asian traffic volume exceeded that of both the Asia/Europe and Transatlantic services. In 2000 the intra-Asian service reached 8.5 million TEUs, 
accounting for 18 percent of the world's total container traffic. In addition, the TransPacific service accounted for 24 percent of the world's container traffic (12 million TEUs). Therefore, the Trans-Pacific container service have outpaced in the rest of the world. Clearly, due to the rise in intra-Asian service and Trans-Pacific service, East Asia, with its buoyant economic growth, has become the new emerging force in the world's container traffic As noted, between 1985 and 2000 container throughput in East Asia rose from 16 million TEUs to 119 million TEUs, accounting for almost 29 percent and over 43 percent, respectively, of the world's total container tonnages. Not surprisingly, East Asia has some of the world's premiere hub ports. By 2001 Singapore, Hong Kong, Busan, Kaohsiung, and Shanghai (China) were among the world's top 10 ports. 9

This description of market structure was tested using measures of dispersion. Table 6 (a to $\mathrm{c}$ ) reports the $\mathrm{H}$ values for three combinations, previously outlined in Table 1 . As noted values of $\mathrm{G}$ and $\mathrm{H}$ have decreased in al observation years in categories $I I$ and III, which indicate fall of concentration and rise of diversification in the container port sector. Some of the findings are noteworthy in this context.

In category $\mathrm{I}, \mathrm{H}$ values for both East Asia and the total group have increased between 1985 and 2000, though had fallen for the USA and EU has fallen. While there is an increasing degree of concentration between economic blocs in world container port system between 1985 and 2000, there is a clear symptom of rising disparity in the world's container port system. In 1985, according to the H, values the most concentrated maritime zone was East Asia and the least concentrated zone was South Asia; this result was unchanged until 2000. Plausibly, these differences reflect the spectacular economic growth of the East Asian economy that, in turn, have generated huge container traffic (see Table $7(\mathrm{a}, \mathrm{b})$ ). These findings suggest that the hinterland of East Asia's port system has been extended markedly.

9 However, there is also evidence of a shift in the dominant container hub centre within East Asia. In the early 1970s, the Port of Kobe and the Port of Yokohama were the gateway ports of East Asia. Until the South Hyogo Earthquake in 1995 the Port of Kobe had kept the No.6 position in world container port rankings. However, the Port of Hong Kong, the Port of Singapore, the Port of Kaohsiung and the Port of Busan are ranked in the group of world top 10 ports, while Port of Kobe has plummeted to position 23. These drastic changes in ranking stem from shifts in world commodity flows, reflecting the globalization of the East Asian economy. Another reason comes from intense competition within the container marine transport market, particularly in the Asian-Pacific and Asian-Europe markets, where shipping companies are very competitive and inter-port competition has intensified. 
Table 7(a). Average Annual Growth Rate of GDP

\begin{tabular}{l|c|c}
\hline Region/Country & $\begin{array}{c}\mathbf{1 9 8 0 - 1 9 9 0} \\
(\boldsymbol{\%})\end{array}$ & $\begin{array}{c}\mathbf{1 9 9 0 - 2 0 0 0} \\
(\boldsymbol{\%})\end{array}$ \\
\hline \hline World & 3.00 & 3.40 \\
\hline East Asia & 7.70 & 9.50 \\
\hline Sub-Saharan Africa & 1.90 & 2.10 \\
\hline Latin America \& the Caribbean & 1.60 & 2.60 \\
\hline Middle East \& North America & 0.80 & 3.00 \\
\hline India & 5.80 & 6.20 \\
\hline China & 10.20 & 10.00 \\
\hline Indonesia & 6.10 & 4.70 \\
\hline Thailand & 7.60 & 3.90 \\
\hline Malaysia & 5.20 & 5.00 \\
\hline Philippines & 1.00 & 5.80 \\
\hline Hong Kong & 6.50 & 5.00 \\
\hline Singapore & 6.00 & 5.30 \\
\hline Taiwan & 6.00 & 4.70 \\
\hline Japan & 2.30 & 2.20 \\
\hline Korea & 5.70 & 4.80 \\
\hline
\end{tabular}

Source: IMF, World Economic Outlook, Various issues.

In category II, in 1985, according to $\mathrm{H}$ values, the three most concentrated maritime countries (in ascending order) were the EU, USA and Japan and the least concentrated countries were Bangladesh, Pakistan and Sri Lanka. Out of 16 countries, Bangladesh was the least concentrated country in 1985 and EU was the most concentrated country. Since the upsurge of container traffic in East Asia a redistribution of traffic across the globe started occurred. Table 8 presents the shares of the maritime countries in world container traffic from 1985 to 2000 . Generally, concentration has fallen in 1990, 1995, and 2000. In 2000, world container port traffic with CAGR of above 20 percent per annum became 225.30 million TEUs, an increase of 300 percent over 1995. During this period, Hong Kong, Singapore, and Korea acquired a higher share of the world container traffic, but, at the same time, the shares of the USA, EU, and Japan fell. This has been reflected in the fall in concentration and the rise of competitiveness between 1985 and 2000 in the East Asian container port system: $\mathrm{H}$ values had decreased to 0.1302 , from 0.1833 in 1985 . Generally, container ports have deconcentrated within the more diversified environment.

East Asia has emerged as the world's largest container handling region. Today, East Asia shares 43.3 percent of the world's container traffic, which was 28.5 percent 15 years ago; during the same period shares in world container traffic in the USA and EU have declined to 12 percent and 19 percent, respectively. To some extent, this phenomenon is a symptom of the equalisation of world container traffic since 1985; 
East Asia's share has increased, while the shares for the USA and EU have both declined. But how has container traffic been distributed among East Asian countries and what has been its level of concentration and competitive environment? To comprehend these trends, let us turn to Table 6(c).

Table 7(b). Merchandise Trade of East Asia in 2001

\begin{tabular}{c|l|r|r|r|l|r|r}
\hline \multicolumn{4}{c|}{ Export } & \multicolumn{5}{c}{ Import } \\
\hline Rank $^{1}$ & Country & $\begin{array}{c}\text { Value } \\
\text { (US\$bn) }\end{array}$ & $\begin{array}{c}\text { Share } \\
(\%)\end{array}$ & Rank $^{1}$ & Country & $\begin{array}{c}\text { Value } \\
\text { (US\$bn) }\end{array}$ & $\begin{array}{c}\text { Share } \\
(\%)\end{array}$ \\
\hline \hline 3 & Japan & 403.50 & 6.60 & 3 & Japan & 349.10 & 5.40 \\
\hline 6 & China & 266.20 & 4.30 & 6 & China & 243.60 & 3.80 \\
\hline 10 & Hong Kong & 191.10 & 3.10 & 10 & Hong Kong & 202.00 & 3.10 \\
\hline 13 & South Korea & 150.40 & 1.50 & 13 & South Korea & 141.10 & 2.20 \\
\hline 14 & Taiwan & 122.50 & 1.30 & 16 & Taiwan & 107.30 & 1.70 \\
\hline & Total & 1133.70 & 18.40 & & Total & 1043.10 & 16.20 \\
\hline & World & 6155.00 & 100.00 & & World & 6441.30 & 100.00 \\
\hline
\end{tabular}

Note: 1 . Refers to the world ranking

Source: Yap et al. (2003)

In 1985, according to H, container traffic in Japan, Taiwan, and Hong Kong were the first three most concentrated countries whereas Indonesia, Thailand, and Malaysia were the least concentrated. In 2000, Singapore and China appeared as the top two most concentrated countries and replaced Japan and Taiwan on the list. On the other hand, the Republic of the Philippines has appeared as one of the least concentrated countries and is placed in a league together with Thailand and Indonesia in the East Asian region. Shares of Hong Kong, China, and Singapore in world container port traffic have increased substantially between 1985 and 2000, while container traffic for Japan and Taiwan has declined. The most remarkable achievement over this period was made by China as her share of world container traffic increased to 7.7 percent in 2000 (see Table 8). 
Table 8. Share of East Asian Countries in World Container Traffic

\begin{tabular}{|c|c|c|c|c|c|c|c|c|}
\hline Country & $\begin{array}{l}1985 \\
(\%)\end{array}$ & $\begin{array}{l}1990 \\
(\%)\end{array}$ & $\begin{array}{l}1995 \\
(\%)\end{array}$ & $\begin{array}{c}1996 \\
(\%)\end{array}$ & $\begin{array}{l}1997 \\
(\%)\end{array}$ & $\begin{array}{l}1998 \\
(\%)\end{array}$ & $\begin{array}{l}1999 \\
(\%)\end{array}$ & $\begin{array}{l}2000 \\
(\%)\end{array}$ \\
\hline Hong Kong & 4.09 & 5.96 & 9.14 & 8.93 & 8.82 & 8.01 & 8.30 & 8.03 \\
\hline Singapore & 3.04 & 6.10 & 8.63 & 8.59 & 8.55 & 8.32 & 8.17 & 7.59 \\
\hline Japan & 9.87 & 9.29 & 7.73 & 7.32 & 6.59 & 5.78 & 6.20 & 6.05 \\
\hline Taiwan & 5.50 & 6.37 & 5.72 & 5.22 & 3.45 & 3.45 & 3.58 & 3.30 \\
\hline Korea & 2.23 & 2.74 & 3.28 & 3.37 & 3.45 & 3.55 & 3.59 & 3.79 \\
\hline China & 0.80 & 1.41 & 3.41 & 3.61 & 3.45 & 5.56 & 6.75 & 7.72 \\
\hline Malaysia & 0.70 & 1.04 & 1.51 & 1.69 & 1.80 & 1.66 & 2.02 & 2.05 \\
\hline Indonesia & 0.41 & 1.08 & 1.49 & 1.17 & 1.16 & 1.21 & 1.36 & 1.71 \\
\hline Philippines & 1.14 & 1.64 & 1.23 & 1.55 & 1.52 & 1.34 & 1.44 & 1.60 \\
\hline Thailand & 0.72 & 1.26 & 1.43 & 1.36 & 1.27 & 1.45 & 1.48 & 1.45 \\
\hline East Asia ${ }^{1}$ & 28.49 & 36.90 & 43.58 & 42.80 & 40.05 & 40.34 & 42.89 & 43.28 \\
\hline
\end{tabular}

Note: 1 . Considers aforementioned 10 countries only.

Therefore, the order of concentration in descending order (from most concentrated to least concentrated) using the Herfindahl-Hirschmann Index in 2000 was Hong Kong, China, Singapore, Japan, Korea, Taiwan, Malaysia, Indonesia, Philippines and Thailand. Thus, both ordinal and cardinal measures of port system inequality between 1990 and 2000 reveal that both ranking and levels of container throughput have been diverging in the key economic blocs, whereas East Asian countries have been converging. And, the measure of dispersion bears sufficient testimony that, in terms of levels of container throughput, East Asian countries show a tendency towards more competition during the last decade whereas inter-bloc competitive environment in the container port system is fading away.

Table 9. Concentration of Container Traffic in Major East Asian Hubs

\begin{tabular}{l|c|c|c|c|c|c}
\hline \multirow{2}{*}{ Port } & \multicolumn{2}{|c|}{$\begin{array}{c}\text { Share in World } \\
\text { Container } \\
\text { Throughput (\%) }\end{array}$} & \multicolumn{2}{c|}{$\begin{array}{c}\text { Share in East } \\
\text { Asia Container } \\
\text { Throughput (\%) }\end{array}$} & \multicolumn{2}{c}{$\begin{array}{c}\text { Share in Country's } \\
\text { Container } \\
\text { Throughout (\%) }\end{array}$} \\
\cline { 2 - 7 } & $\mathbf{1 9 9 1}$ & $\mathbf{2 0 0 1}$ & $\mathbf{1 9 9 1}$ & $\mathbf{2 0 0 1}$ & $\mathbf{1 9 9 1}$ & $\mathbf{2 0 0 1}$ \\
\hline \hline Hong Kong & 5.90 & 8.60 & 20.00 & 23.00 & 100.00 & 100.00 \\
\hline Singapore & 6.10 & 7.50 & 22.00 & 21.00 & 100.00 & 100.00 \\
\hline Busan & 2.15 & 4.25 & 10.00 & 16.00 & 85 & 75.00 \\
\hline Kaohsiung & 5.92 & 4.00 & 12.00 & 14.00 & 90 & 80.00 \\
\hline Shanghai & & 2.50 & & 6.00 & & 35.00 \\
\hline
\end{tabular}

Source: Containerisation International, Various Issues 
These findings raised the question: is the geographical positioning of the hub ports such as Singapore, Hong Kong, Kaohsiung, and Busan due to container port system equalization? We believe there is qualified support for this position. In our analysis, Singapore and Hong Kong are both treated as separate countries, while Kaohsiung and Busan also account for approximately 70 percent to 80 percent of the total container traffic in their respective economies. Collectively, the region's four leading hub ports, which represent four countries in our study, accounted for 25 percent of the world's container traffic, and experienced higher and rising $\mathrm{H}$ values. Table 9 shows that the market share of East Asia's five major hubs between 1991 and 2001 have increased heavily; together these five ports share approximately 25 percent of world container cargo and 80 percent of East Asian container traffic respectively. Interestingly, except for Shanghai, the four hubs share more than 75 percent of their country's total container traffic and are heavily dependent on transhipment traffic. Since the hub port development strategy is based on the assumption that the larger a port is stronger is its competitive power. Naturally, these hubs rely mostly on transhipment traffic. Thus, these four ports are largely responsible for the substantial concentration of container traffic tonnages in East Asia. Due to this rising concentration, East Asia has become the golden hub for terminal operators. Today, as many as ten terminal operators are present in the region: HPH operates 14 terminals, PSA, P\&O and CSX each runs six terminals, COSCO and APM each operates four terminals, and finally, MTL and CMH run three each (see Table $10(\mathrm{a}, \mathrm{b})$ ).

Table 10(a). International Terminal Operators in East Asia

\begin{tabular}{l|l|l|l}
\hline Port & $\begin{array}{l}\text { Before 1997 } \\
\text { Terminal Operator }\end{array}$ & Port & $\begin{array}{l}\text { After 1997* } \\
\text { Terminal Operator }\end{array}$ \\
\hline \hline Dalian & PSA & Chiwan & MTL \\
Gaolan & HPH & Daxie & CMH \\
Hong Kong & COSCO, CSX, HPH, MTL & Fuzhou & PSA \\
Jakarta & HPH & Guangzhou & PSA \\
Jiangmen & HPH & Incheon & PSA \\
Jiuzhou & HPH & Kitakyushu & HPH \\
Kaohsiung & APM & Laem Chabang & P\&O, HPH \\
Kobe & APM & Manila & P\&O \\
Nanhai & HPH & Mawan & CMH \\
Qingdao & COSCO & Muara & PSA \\
Shanghai & COSCO, HPH & Ningbo & HPH \\
Shantou & HPH & Busan & CSX, HPH \\
Shekou & P\&O & Qingdao & P\&O \\
Singapore & PSA & Shanghai & APM \\
Xiamen & HPH & Shekou & MTL \\
Yantian & COSCO, HPH & Surabaya & P\&O \\
Yokohama & APM & Tianjian & CSX \\
\cline { 1 - 2 } & & Vostochny & CSX, P\&O \\
& & Xiamen & CSX \\
& & Yantai & CSX \\
& & Zhangzou & CMH \\
\hline
\end{tabular}

Note: * As on December 2003.

Sources: 1. Websites of terminal operators, 2. Yap et al. (2003) 
Table 10(b). Terminal Operators and Their Container Terminals in East Asia

\begin{tabular}{c|l|c}
\hline Sr. No & Operator & $\begin{array}{c}\text { No of } \\
\text { Terminals* }\end{array}$ \\
\hline \hline 1 & HPH & 14 \\
2 & PSA & 4 \\
3 & P\&O & 6 \\
4 & CSX & 6 \\
5 & COSCO & 4 \\
6 & APM & 4 \\
7 & CMH & 3 \\
8 & MTL & 3 \\
\hline
\end{tabular}

Note: * As on December 2003

East Asia has over 43 percent of the world's container trade, which is set to rise to around 52 percent in 2010 - equal to a massive 245 million TEUs,. This trend would make the region the dominant world center with the highest intensity of shipping liner operations. This result, coupled with other findings, suggests that East Asia has been benefiting from globalization. Thus, the task is to keep the system competitive. Intercountry and inter-port competition in East Asia in the container handling is expected to continue as the centre of gravity for cargo volumes has shifted to China. Competition may stem from the concentration of shipping line services within the primary load centers. These primary load centers will compete intensely with ports located in close proximity and with overlapping hinterlands: notably Hong Kong vs. Shenzhen, Busan vs. Gwangyang, Shanghai vs. Ningbo and Singapore vs. Tanjung Pelepas. It is still uncertain how long the present days leading hub/feeder ports will be able to retain their positions when container vessel sizes are increasing rapidly to enable shipowners gain the benefits of scale economies. According to Kuroda et al. (2002), deployment of 6000 TEUs vessels in the marine transport sector is likely to change the routing network, particularly among those lines which are linked with hub/feeder ports in East Asia. ${ }^{10}$ While these developments could lead to intense competition, opportunities are also presented for ports to cooperate to better serve the economic interests of their hinterland.

${ }^{10}$ Some of the pioneering results of Kuroda et al worth noting: (a) Before 6000 TEU vessels are fully employed in the market in 2010, Hanshin, Busan Hong Kong and Singapore will be pre-eminent and the present routing network will not change so much; (b) however, when 6000 TEUs vessels are fully employed in the market, the routing network will be drastically changed to the "Hub and Spokes" type network, and Busan, Hong Kong and Singapore will be the Hub ports; (c) Hub ports will enjoy "economies of scale" by 6000 TEU vessels and also "the economies of density"; (d) according to the change of network shape, tariffs on almost all routes will be reduced, except for the Shanghai route, because of the so-called positive feedback effects in economics; and (e) Japanese ports will loose the traditional role as a gate port in East Asian region. 


\section{CONCLUSIONS}

World trade, particularly container port throughput, is developing much faster than the output from world production. Hence, there is a growing need for improving and increasing port capacities worldwide. Further pressure on ports stems from the rapid increase in container vessel sizes and a shift in the balance of power between shipping line as the market power of some companies has increased through mergers and acquisitions. To date, the top 20 shipping lines control 80 percent of the capacity of the fully cellular container vessels. In order to cope with these challenges, disparities among the container ports in terms of their scale economies have to be reduced by encouraging competition between countries and within countries.

A high share in container traffic does not necessarily mean that the terminal operator is anti-competitive. One has to consider both market structure and market conduct issues in tandem together with market performance. Any consideration of antitrust behaviour requires a measure of concentration with the existing market structure as the first step towards a deeper understanding of how well the market is functioning. Also many industries, almost by definition, are highly capital-intensive (typically with high upfront fixed an sunk costs but relatively low incremental costs). These industries display economies of scale and, often, of economies of scope or density. Concentration in such markets, as detected by conventional measures, is only to be expected because the viable or minimum efficient and sustainable level of production is likely to be quite high relative to the market demand for individual operators/firms. Does that mean that such an industry is doomed to be uncompetitive or anti-competitive? This assumption is not the case. For example, market contestability, rather than the old-fashioned plain vanilla market competitiveness, would then be a better index or predictor of conduct by an individual country, port or terminal operator.

The other most important message is that countries for the most part have avoided transferring public monopolies to private ones. However, the potential for oligopolistic behaviour remains. This is due in large measure to the capital-intensive nature of port operations (vying for a relatively 'limited' market). The challenge in such environments where the 'public interest' may be seen to be under threat is to maintain a proper balance between public and private sector interests. This means that we need to let market forces work by encouraging competition and avoiding strict regulation (e.g. imposing tariffs). Regulators will never have the full story of an operator's cost structure, and hence regulation can effectively 'distort' the very market that we are trying to avoid by intervening in the first place.

We know from experience that fierce port operator competition encompasses only a very few rivals, notable Seattle and Tacoma, Singapore and Hong Kong, Rotterdam and Amsterdam, Thus, there is no need to assume that these ports behave anticompetitively. What we need to do is to monitor their competitive behaviour.

Our task is to keep the system competitive. Inter-country and inter-port competition in container handling within Asia is expected to continue as the gravity of cargo volumes has shifted to China and, to lesser extent, India." Competition might result

\footnotetext{
" For example, see De and Ghosh (2004).
} 
from the concentration of services by shipping lines at the primary load centers. These primary load centers will probably compete intensely with ports located in close proximity to each other which share their hinterlands such as Hong Kong vs. Shenzhen, Busan vs. Kwangyang, Shanghai vs. Ningbo and Singapore vs. Tanjong Pelepas. It is uncertain how long the leading hub/feeder ports will retain their positions when container vessel sizes are increasing rapidly to gain the benefit of scale economies. On deployment of 6000 TEUs vessels in the marine transport sector is likely to change the routing network particularly those that are linked with hub/feeder ports in Asia. While these developments could lead to intense competition, opportunities are also present for ports to cooperate with each other to serve the general economic interests of their hinterland better.

Interest in the world container port system concentration stems from the fear that a few giant maritime countries (or ports) may not be inhibited from penetrating the markets of other ports. Collusive arrangements may also arise. The arrangements may involve market-sharing agreements to moderate competition-a strategy that could work against globalization. Thus this paper has determined the degree of concentration of the world's container port system with special reference to East Asian countries. In East Asia the degree of concentration from largest in Hong Kong through China, Singapore, Japan, Korea, Taiwan, Malaysia, Indonesia, the Philippines, to the smallest in Thailand

\section{REFERENCES}

Barro, R.J, and X. Sala-i-Martin (1995) Economic Growth, New York: McGraw Hill.

Bertrand, Joseph (1883) "Theorie Mathematique de la Richesse Social" (loosely translated as Mathematical Theory of Social Welfare), Journal des Savants, Paris, September, pp. 499-508.

Cournot, A. Augustin (1927) Researches into the Mathematical Principles of the Theory of Wealth. 1927 reprint of 1897 translation, New York: Macmillan. (Paper appeared originally in 1838).

De, P (2003) "Indian Ports in the Era of Globalisation", World Port Development, 3(10), pp. 17-22.

De, P, and B. Ghosh (2002) "Productivity, Efficiency and Technological Change in Indian Ports", International Journal of Maritime Economics, 4(4):. 348-368.

De, P, and B. Ghosh (2004) Trade, Infrastructure and Transaction Costs: An Investigation ` with Asian Economies, Unpublished paper presented at the Northeast Area Studies Centre of Institute of Developing Economies (JETRO), Japan, on April 30, 2004.

De, P, and Ro-Kyung Park (2003a) "Container Port System Concentration in East Asia", Conference Proceedings, COPEDEC VI, Colombo.

De, P, and Ro-Kyung Park (2003b) "Container Port System Concentration", Transportation Quarterly, 57(4), pp. 69-82. 
Everett, Sophia (2002) "Corporatisation Legislation: The Key to the Effective Port Management", Conference Proceedings, IAME 2002, Panama.

Ghosh, B, and P. De (2000) "Impact of Performance Indicator and Labour Endowment on Traffic: Empirical Evidence from Indian Ports", International Journal of Maritime Economics, 2(4), pp. 259-281.

Herfindahl, Orris C. (1950) Concentration in the Steel Industry, Doctoral Dissertation, Columbia University, New York.

Hirst, J (2000) "Future Management Trends in Australian Ports" Paper Presented at AAPMA Conference PAN PACIFIC 2000 "Beyond the Horizon".

Hoffmann, Jan (1998) "Concentration in Liner Shipping: Causes and Impacts", World Sea Trade Service Review, 1(2), pp. 68-74.

Hoffmann, Jan (2002) “Concentración y Especialización, sus Causas,y sus Implicaciones para Centroamérica (Concentration and Specialization, Causes, and Implications for Central America)", presentation to COCATRAM, April 2002, citing Alphaliner (BRS Shipbrokers Group), www.alphaliner.com.

Jung, Bong-Min (2003) "Concentration and Hub Strategy of Container Ports", Conference Proceedings, IAME 2003, Seoul.

Kent, Paul E (2002) "Monitoring for Port Antitrust Behaviour: An Operational Model and Future Challenges", Conference Proceedings, IAME 2002, Panama.

Kent, Paul, E, and Asaf Ashar (2001) "Port Competition Regulation: A Tool for Monitoring for Anti-Competitive Behaviour", International Journal of Maritime Economics, 3, pp. 27-51.

Kuroda, Katsuhiko, Mikio Takebayashi, and Tsuji Toshiaki (2002) "International Container Transportation Network Analysis Considering the Post-Panamax Class Container Ship", Conference Proceedings, $30^{\text {th }}$ International Navigation Congress of International Navigation Association (PIANC), Sydney.

Sheshkin, David J (2000) Handbook of Parametric and Semiparametric Statistical Procedures, Chapman and Hall, London.

Trujillo, L, and T. Serebrisky (2003) "Market Power: Ports", Note Number 260, The World Bank, Washington, D.C.

Tschoegl, Adrian E (1982) “Concentration among International Banks," Journal of Banking and Finance, Vol. 6. No. 2, pp. 69-86.

UNCTAD (2003) Review of Maritime Transport, Geneva.

Yap, W. Y, Jasmine, S. L. Lam, and Theo Notteboom (2003) "Developments in Container Port Competition in East Asia", Conference Proceedings, IAME 2003, Seoul. 